\title{
A Simple Method and Apparatus for Obtaining Water Samples in a Thin Layer
}

\author{
Masahiro KAJIHARA**
}

\begin{abstract}
A sampler that is consisted of an air tank and a junction chamber has been designed to collect the waters of about one hundred $\mathrm{m} l$ from each vertically five adjacent depths into the junction chamber by hydrostatic pressure. Also the waters of larger volume can be obtained into the separated bottles from the chamber. This sampler is quite useful for research not only in shallow water, estuary and lake, but also for sampling waters near sea surface and sea floor.
\end{abstract}

\section{Introduction}

While many sampling devices have been developed, there is no adequate sampler that can obtain water in the thin layer. Reversing or remote-closing bottles are widely used, but these are not suitable for studying the detailed vertical distribution in shallow water, and in addition most of them need a wire and a messenger. The devices using suction system are one of the availabe method to overcome these difficulties, though the sampled water will be contaminated with the air and also they can not collect the water of different depths at the same time. The sampler developed in this paper was used one of the suction system, however it was designed paying attention to these difficulties,

that is,

(1) rapid sampling waters of five different depths in the restrictive layer,

(2) sometimes, sampling waters of arbitrary larger volume, and

(3) operating without the electric energy supply, also the use of wire and messenger system.

Accordingly, this sampler will be appreciable for the studies in coastal oceanography, limnology and also the problems of micro-oceanography.

\section{Instrument and operating principles}

The basic devices are mainly consisted of an air tank and a junction chamber shown in Fig. 1.

* Received December 22, 1967

** Faculty of Fisheries, Hokkaido University
The air tank is for "Aqualung" on which a pressure regulator is mounted to regulate air flow freely. The junction chamber shown in Fig. 2, made of steel $(180 \phi \times 28.5 \mathrm{~cm})$, is held to pressure tight, which are used for the container of bottles or a junction of air pipes. On the removal cover of the junction chamber, six pipes (one is a spare) for water intake and one mouth for air flow are attached. The pipes are made of brass and in which hard vinyl pipes are inserted in order to avoid the corrosion and the chemical reaction by water. The air flow mouth made of brass is connected to the air tank by the rubber hose.

The use of the sampler are mainly parted into two cases, one for sampling waters which are offered to the chemical analysis of dissolved gasses or some properties, and the other for

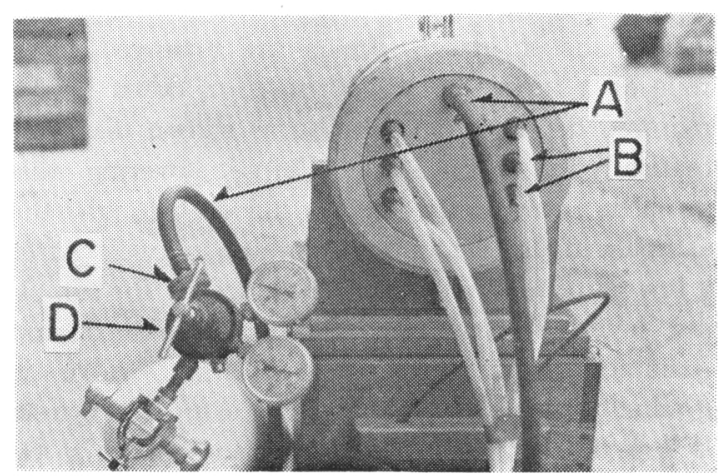

Fig. 1. Apparatus.

A : rubber hose for air-flow

$B$ : vinyl tubes for water sampling or air-drain

$C$ : air-drain valve

D : regulator 


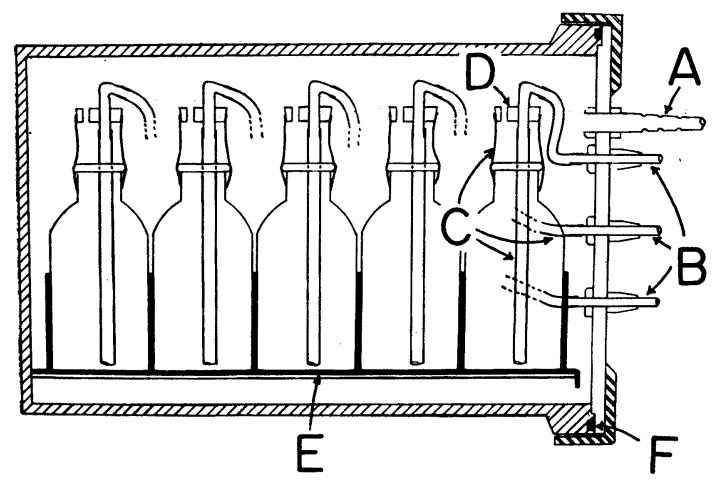

Fig. 2. Junction chamber and sampling bottles.
A: air-flow mouth
$B$ : hard vinyl pipes
C: vinyl tube
D: rubber stopper
$\mathrm{E}$ : case for bottles
$\mathrm{F}$ : O-ring

sampling waters of larger volume. In the former the volume of sampling water is limitted with the size of bottle and also of the junction chamber, but the operation is simple and easy. As shown in Fig. 2, sampling bottles are put in a case and are housed in the junction chamber. In our experiments, regarding the dissolved oxygen analysis by the Winkler method, an adapter is so attached on the sampling bottle as to cover the loss of sampled water by the volume of the vinyl tube which is inserted in the bottle. The inner and outer ends of intake pipes of the junction chamber are connected by vinyl tubes to the bottles and to the one-way vanes respectively (Nishimaki vane made of glass), which are arranged on a rope or a frame so as to be sunk down in the required depth. Its operation is shown diagrammatically in Fig. 3-A. Before lowering this sampler, compressed air is filled through the sampler in order to prevent water inflow. After a few minutes that the disturbance in the sampling layer is considered to be diminished and remained stationary, the air-drain valve is gradually opened, and then the sampling waters will be flowed into the bottles automatically by hydrostatic pressure. In the case of sampling near water surface, hydrostatic pressure is too small to operate the one-way vane, and therefore the air tank and the one-way vane can not be used. In practice, hard vinyl pipes are setted in

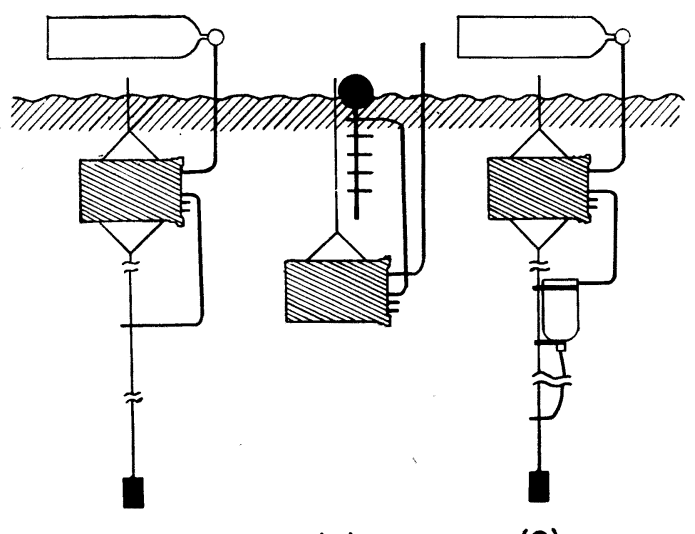

(A)

(B)

(C)

Fig. 3. Operating method for sampler.

place of the one-way vanes on a floating rod near water surface, and the junction chamber is gradually lowered down below the sampling layer. Waters are also automatically flowed into the bottle as shown in Fig. 3-B.

The other case of using this sampler is to collect the waters of larger volume, leaving out of consideration for air contamination. Fig. 3-C is the schematic diagram of this method. Both the bottles in the junction chamber and the one-way vanes are taken off, and larger bottles are suspended out of the junction chamber. These bottles and the junction chamber are filled with water beforehand, and the intake pipes with vinyl tubes which are connected to the bottles are lowered to be sunk down to the required depth . Compressed air is letted into the sampler till the pressure attains equilibrium to the outer hydrostatic pressure, then water filled in the sampler is exhaused. Latter procedure of sampling is the same as described above. This sampling method has a advantage in a point that the bottle is not required to be pressure tight, thought there is the inherent fault that the weight is needed to overcome the buoyancy of bottle. This method is also applicable to the water sampling of larger volume near water surface by combination with the method shown in Fig. 3-B.

In all cases, care should be taken to the point that the mouths of sampling pipes or vanes must be held above the junction chamber when the sampling devices are raised over the water surface, lest the sampled water in the bottle should flow 
out by "siphon".

\section{Test and an example of oxygen measure- ment}

The deeper the sampling depth, the more forcibly water will flow into the bottle, when the air-drain valve is opened. And sampled water will be contaminated with compressed air. The test was previously carried out on board of an anchored boat to provide effective data concerning with the contamination with compressed air. The sampling depth was $5 \mathrm{~m}$ and $10 \mathrm{~m}$, and the air pressure in the sampler was both $2.0 \mathrm{~kg} / \mathrm{cm}^{2}$. Table 1 shows the results. The air-drain time was adjusted by opening the valve slightly but constantly. From the results, values of dissolved oxygen in each depth are almost the same on the whole. However, in the sampled waters taken in the shorter air-drain time, the slight fluctuations of the values are seen. It mays be caused by the inhalation of water, which yields the violent disturbance in the bottle and interrupts the smooth out-flow of the contaminated water. Therefore, in the case of the longer air-drain time, these values are remained close to a constant in the range of error. In practice, the air-drain time in several minutes will cause the disturbance around the mouths of sampling pipes or vanes due to the rapid inhalation and it makes the object of sampling water in the restrictive layer in meaningless. Accordingly, it should be noted that the air-drain valve should be once shutted up when the pressure difference between the inner pressure of the junction chamber and the outer hydrostatic pressure are decreased, and some minutes after when the disturbance is considered to be diminished, the valve should be

Table 1. Dissolved oxygen values in several air-drain times.

\begin{tabular}{l|c|c|c|c|c}
\hline \multicolumn{3}{c|}{ Depth $5 \mathrm{~m}$} & \multicolumn{3}{c}{ Depth $10 \mathrm{~m}$} \\
\hline $65(\mathrm{sec})$ & 150 & 180 & 83 & 120 & 210 \\
\hline $5.85(\mathrm{ml} / l)$ & 5.86 & 5.85 & 5.93 & 5.94 & 5.93 \\
5.96 & 5.88 & 5.86 & 6.12 & 5.97 & 5.94 \\
5.97 & 6.00 & 5.86 & 6.14 & 6.11 & 5.94 \\
6.10 & 5.91 & 5.87 & 6.25 & 6.15 & 5.95 \\
6.15 & 6.18 & 5.88 & 6.38 & 6.23 & 5.97 \\
\hline
\end{tabular}

gradually opened again. In this sampler, if the hydrostatic pressure differences depending on the each position of sampling mouth are not in consideration, sampled waters which are overflowed from the bottles into the junction chamber are about 17 times of the volume of each bottle. Therefore, the washing effect of the bottle will be

Table 2. Comparison of the samplers by dissolved oxygen values.

\begin{tabular}{l|llllll}
\hline New sampler & $5.94(\mathrm{ml} / l)$ & 5.96 & 5.97 & 5.97 & 5.97 \\
\hline Nansen bottle & $5.94(\mathrm{~m} l / l)$ & 5.96 & 5.97 & & \\
\hline
\end{tabular}

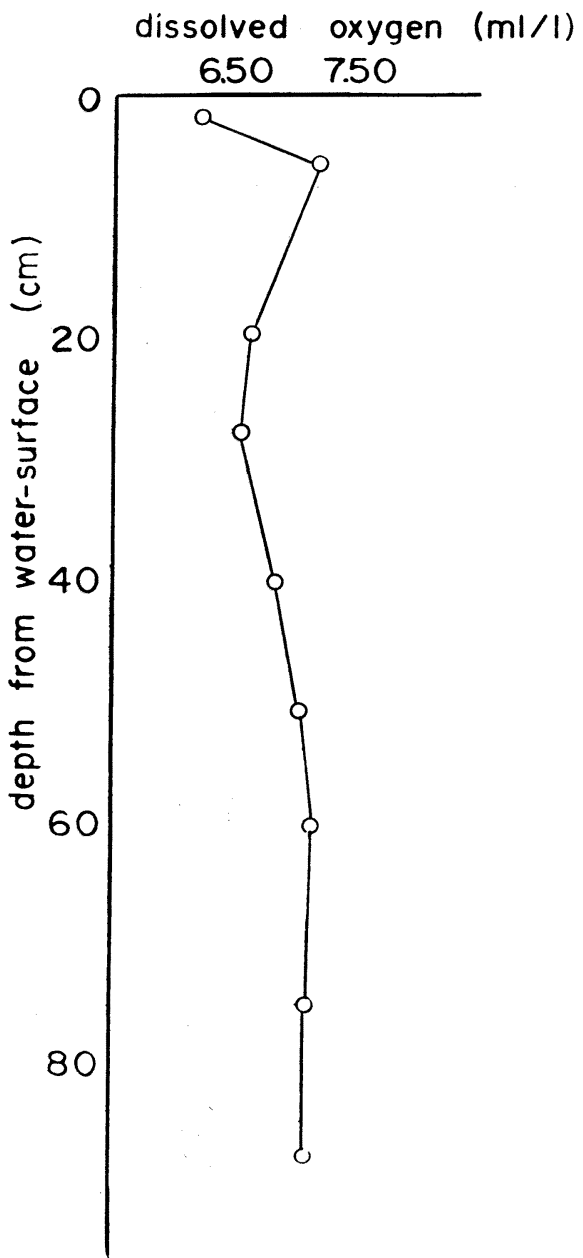

Fig. 4. An example of the detailed distribution of dissolved oxygen near water surface in the shallow pond (sampled at $15^{\mathrm{h}} 50^{\mathrm{m}} \sim$ $16^{\mathrm{h}} 15^{\mathrm{m}}$ on July 19,1967$)$. 
expected. Table 2 shows the results of dissolved oxygen values obtained with the new sampler and the Nansen bottle. Obviously, there are almost no difference between the two samplers in the range of error. Fig. 4 shows an example of the vertical distribution of dissolved oxygen obtained in shallow pond of $1 \mathrm{~m}$ deep on July 19, 1967. Water sampling was parted into two times, one in the shallow layer and another in the deeper layer (below $40 \mathrm{~cm}$ deep). In the latter case, the air tank and the one-way vane were used. Maximum of dissolved oxygen seen in Fig. 4 may be depended on the phytoplankton and the exchange of oxygen between the atmosphere and the water.

\title{
微細な垂直分布採水を目的とした簡易採水法 並びにその採水器
}

\begin{abstract}
梶原昌弘
要旨 数多くの採水器がそれぞれの目的に応じて製作さ れ用いられているが, これら従来の採水器は浅海に打け る垂直分布, あるいは最近注目されつつある表層ないし は海底近傍の微細な分布を目的とした採水には必ずしも 適当ではない.ここで述べている採水法は電動ポンプあ るいは注射器などを利用する suction system の一種に 属するが，水圧をそのまま利用して採水することによ

混入を解決して溶在ガスなどの分析を目的とした試水を 容易飞採水可能にした. 採水器は主としてアクアラング ボンベと junction chamber から成り立つが, junction chamber 飞採水瓶を収納して用いる時は深さの異なる 5 層から各々 $100 \mathrm{ml}$ の水を同時飞採水することが可能 であり,一方この junction chamber を空気の連結筒と して用いる時は任意の多量採水が可能である.
\end{abstract} り, 採水層を薄く, 且つ吸引の際にとかく避け難い空気 